\title{
Mixed couples in France. Statistical facts, definitions, and social reality
}

\author{
Beate Collet \\ Université Paris IV-Sorbonne. GEMASS \\ beate.collet@paris-sorbonne.fr
}

Received: 17-11-2010

Accepted: 09-11-2011

\begin{abstract}
Mixed couples are usually defined as combining national, cultural, racial or religious differences, but these definitions are generally elaborated only empirically. More recently, researchers have proposed the concept of "mixedness" which goes beyond those descriptive factors of difference. The French national migration tradition and the Citizenship Act also helps to show why it is not easy to reach a single definition.

A detailed look at statistical realities illustrates how complex it is to count mixed couples. The figures differ if we consider mixed marriages as flows (new marriages each year) or as stock (how many people live in a mixed family). They also vary depending on what differences — cultural belonging or nationality - are taken into account. Many Frenchforeign marriages bring together people who have the same cultural identities.

From the sociological point of view, mixed marriage should be defined as combining perceived differences and existing social order and norms. Studies on mixedness look at how socially constructed differences in contact, e.g. in private life, influence social relations and modify social realities. Mixed couples experience specific social constraints due to the migration situation of at least one of the partners, and therefore these couples need time to learn to manage the cultural and social differences in their relationship. Differences between the partners due to their cultural and social affiliations or gender roles are not equal and also influence the transcultural hybridisation process, sometimes even hindering it considerably.
\end{abstract}

Key words: mixedness; French-foreign marriages; cultural difference; gender roles; social constraints; migration policy; transcultural hybridisation; conjugal relations.

\section{Resumen. Parejas mixtas en Francia. Estadisticas, definiciones y realidad social}

Una pareja mixta se define generalmente como la combinación de las diferencias nacionales, culturales, raciales o religiosas. Pero estas definiciones generalmente se elaboran sólo empíricamente. Más recientemente, los investigadores han propuesto el concepto de «mestizaje», que va más allá de los factores descriptivos de la diferencia. La tradición de 
migración nacional francesa y la Ley de ciudadanía también ayudan a entender por qué no es fácil llegar a una definición única.

Una mirada pormenorizada a la realidad estadística ilustra lo complejo que es contar el número de parejas mixtas. Las cifras difieren si se considera el matrimonio mixto como un flujo (los matrimonios nuevos cada año) o como población (número de personas que viven en una familia mixta). También varían en función de qué diferencias se tienen en cuenta - la pertenencia cultural o la nacionalidad. Muchos matrimonios entre franceses y extranjeros unen a personas que tienen la misma identidad cultural.

Desde el punto de vista sociológico, el matrimonio mixto debería definirse como la combinación de las diferencias percibidas y el orden social existente y las normas. Los estudios sobre el mestizaje tratan de cómo las diferencias sociales en contacto - por ejemplo en la vida privada- influyen en las relaciones sociales y modifican la realidad social. Las parejas mixtas están involucradas en determinadas limitaciones sociales debido a la situación de migrante de por lo menos uno de los cónyuges. Por lo tanto, estas parejas necesitan tiempo para aprender a gestionar las diferencias culturales y sociales en su relación. Las diferencias entre los cónyuges, debidas a sus filiaciones sociales y culturales y a los roles de género, no están en pie de igualdad y también influyen en el proceso de hibridación transcultural, a veces incluso obstaculizándolo considerablemente.

Palabras clave: mestizaje; matrimonios persona francesa-persona extranjera; diferencias culturales; roles de género; limitaciones sociales; política migratoria; hibridación transcultural; relaciones conyugales.

\begin{aligned} & \multicolumn{2}{c}{ Summary } \\ & Introduction $\begin{array}{l}\text { 3. Mixed couples and marriage: } \\ \text { a complex statistical reality }\end{array} \\ &$ 1. State of the Art on mixed couples $\begin{aligned} \text { 4. Some theoretical considerations } \\ \text { in France }\end{aligned} \\ & \begin{aligned} \text { 2. The influence of the French migration } \\ \text { tradition and citizenship Act }\end{aligned} \begin{array}{l}\text { 5. Conclusion } \\ \text { Bibliographic references }\end{array}\end{aligned}$

\section{Introduction}

Research on migrations or foreigners is always linked to a country's national traditions and political and legal contexts. Theoretical and thematic choices in social science are naturally also related to the contextual situation. To see into the French reality of mixed couples, it is important to consider all these points. The aim of this article is to give an overview on theoretical and empirical reality of mixed couples in France. To do so, I first review the state of the art of this field in France, and then I complete with some historical and legal particularities of the migratory context in French society, which is necessary to conduct sociological analysis. Second, I will present statistical facts concerning mixed couples which show that it is not easy to know who is "mixed" and who not, and how many mixed couples there are in France. Looking at nationality is not enough to grasp the meaning of 'mixedness', questions of ethnic belong- 
ing have to be considered too. The statistical uncertainty brings me in a third step to questions of definitions: how is 'mixedness' related to social norms and what can we learn about the place of culture in conjugal relations and family.

Mixed couples are usually defined as combining national, cultural, racial or religious differences. These descriptive factors are not satisfying because they occur often simultaneously but sometimes also differences of that kind do not disturb social norms. Therefore, I will introduce the term 'mixedness' to coin a more sociological definition which stresses on the questions which really matter beyond those descriptive factors.

\section{State of the Art on mixed couples in France}

Studies on mixed marriage, and in later years on mixed couples, have been ongoing in France since the 1960s. Though in the United States, "mixed marriage" refers mainly to interracial or interfaith couples, the French espoused the American sociological tradition and called cross-national couples in France 'mixed', and not 'bi-national' or 'bi-cultural'. In this first phase, studies in sociology and social psychology focused on marriage between French citizens and migrants — foreign workers and students - mainly from the former French colonies in Africa (Algeria or West-Africa) - (Barbara, 1978; Vinsonneau, 1978; Hamad, 1981; Kuoh-Moukoury, 1983), but also on inter-faith marriages (Bensimon/Lautman, 1977) or international couples (French-American or French-German couples) (Varro, 1984, 1995). A first issue of a scientific journal centred on these questions in 1974 (Les mariages mixtes, 1974). All these studies, most of them monographies, analysed the confrontation between cultural, linguistic or religious features within a family and their importance in the education of the children. They also stress having experienced discrimination with other family members (uncles, aunts, in-laws) who do not accept the foreign or in other social relationships (friends, colleagues). They describe the intercultural realities of these families without really driving the analysis further on a general level, e.g. on how intercultural reality is constructed in private life. Interesting questions were of course broached, but by each scholar in an isolated fashion, without aiming for a more collective analysis of that reality or seeking to identify a common research object.

In the early 1990 s, to identify the characteristics of what was thereafter to be known as "conjugal mixity" (mixité conjugale), collective discussions were organized in 1991 and 1995 at the behest of Gabrielle Varro. The journal Hommes \& Migrations dedicated an issue to the subject in 1993 (Les mariages mixtes, 1993). The field continued to be explored by J. Streiff-Fenart (1989), A. Guyaux, C. Delcroix, E. Rodriguez and A. Randane (Guyaux et alii., 1992), A. Hammouche $(1990,1994)$, G. Neyrand and M. M'Sili $(1995,1996)$ and B. Collet (1996), culminating in a first joint venture, publishing the results of the symposium held in 1995 (Philippe et alii., 1998). G. Varro's book, Sociologie de la Mixité in 2003, offered a global presentation of "conjugal mixedness», opening up onto other domains as well, such as social mixedness 
in schools. In 2008, the book directed by B. Collet and C. Philippe achieved a greater degree of intersectionality.

Some of these studies also involved mixed couples formed by persons of immigrant descent (Sad Saoud, 1985; Streiff-Fenart, 1989 and 2000; Hammouche, 1990; Belhadj, 2003, Collet/Santelli, 2003). If one considers their citizenship, these couples are often in fact not "mixed" - both are French citizens - but when their family culture is taken into account, they are of course "mixed". Because of their family education and cultural affiliation, but also due to the social and residential segregation and discrimination immigrant families obtain in France, couples made up of a French person of immigrant descent and a French partner whose parents did not immigrate may be considered as "mixed couples". This is also true, as a more recent study showed (Collet/Santelli, 2008), because their choice transcends the endogamy norms transmitted in their parents' respective families.

At the intersection between family studies and the question of immigration/integration, the field has progressively developed in France, without as yet having attained the legitimacy of other, more visible domains in the social sciences. Thinking on conjugal mixedness grew out of qualitative studies, with socio-cultural differences in the couple as the starting point, but not limiting the analysis to their private life. Every dimension of their reality - juridical, political, economic, cultural, religious and social — was examined, transforming the couple into a remarkable laboratory for studying mixedness in general. The latter studied through couples' experiences has frequently been broached across disciplinary boundaries, considering cultural, gender and social differences all together.

\section{The influence of the French migration tradition and citizenship Act}

As suggested above, holding same citizenship may conceal cultural differences -but different citizenships may also hide cultural similarities. Even though they possess different nationalities, mixed couples may therefore experience cultural proximity because of their similar cultural affiliations. Citizenship is of course an important criterion for legal status, but not necessarily a valid indicator of cultural differences, real or perceived. Migrants of the 1960s and 70 s settled in the countries to which they emigrated (T. Hammar (1994) called them 'denizens', because they do not have citizenship but they are regular residents of the country); their children were raised in France and most of them do have French citizenship. When these children marry a partner who comes from their parents' country of origin - legally a foreigner - they are concluding a "mixed marriage" from a legal point of view, and also because they were socialized in two different societies. But, as they perceive themselves often through more cultural features (as e.g. Algerians, Tunisians or Turks), they do not feel theirs to be a mixed marriage, because they emphasize their similar cultural identities.

France has been a country of immigration since the $19^{\text {th }}$ century. Since that time and according to the Republican tradition inherited from the French 
Revolution, the Citizenship law based on birth in the country stresses integration in the French nation. Over decades, Italian, Polish, Spanish and other migrants have been integrated into the French nation. Since the 60s, labour migrants, mainly from the former French colonies in Africa, became permanently established in France and have contributed to diversifying the origins of the French population. Demographic preoccupations contribute to maintaining this tradition and even in recent years, attempts to abolish or limit integration through citizenship of persons of immigrant descent have failed. Children of migrants who are born in France are French citizen from birth or at the latest when they turn 18, if they attended school in France for a minimum of 5 years.

The French conception of citizenship is thus not ethnically rooted but based on membership in the political community of citizens (Schnapper, 1994). Many French citizens have foreign origins; almost one out of four has at least one foreign grand-parent (Tribalat, 1991). Therefore, as in the U.S. or Great Britain, citizenship and cultural affiliation are not directly linked. The number of foreigners in France is smaller than the number of migrants or immigrant descendants. In January 2005, the Statistical Office in France (INSEE) counted 5 million immigrants, among whom 2 million were French citizens (Régnard, 2007; Ministry of Domestic Affairs). The number of legal foreign residents has been stable for the last ten years, at about 3 million (Régnard, 2007). A representative survey in 1999 showed that 8.8 million people in France were migrants or second generation immigrant descendants (Etude de l'histoire familiale - EHF), corresponding to 15\% of the total French population (Borrel/Simon, 2005).

The situation in France is similar to the situation in the United States or United Kingdom, but it is in a sense inverted compared to Germany, where many of the people born in the country remain foreigners from a legal point of view. The reform of the Staatsangehörigkeitsgesetz (German Citizenship Act) at the end of the 1990s changed the situation for future generations, but the effects are not yet really visible among young adults of immigrant descent today.

The number of foreigners in a country, and therefore the number of "mixed" couples, is directly related to the legal opportunities for integrating citizenship migrants have at their disposal. Bi-national couples are not necessarily bicultural, and some of the couples who do not appear in the statistics on bi-national relationships (because both are "French") are of course bicultural.

It is necessary to be aware of the legal consequences that await nationalforeign couples in a country, even when they feel that they belong to the same culture. Thus, a first important dimension of mixedness, beyond cultural or social issues, is the asymmetry of their legal status. While one partner is a citizen, enjoying all the formal rights of citizenship, the other as a foreigner has to justify his or her presence in the country and must endure restrictions in many domains (jobs, housing, banking, political participation...). Partners in 
a couple are consequently not on an equal footing and that legal fact affects their family realities in a broader sense: unequal opportunities for working, being financially dependent on the partner, women relegated to homemaking, etc.) (Collet, 1993, 1996, 2000).

\section{Mixed couples and marriage: a complex statistical reality}

The quantitative aspects of mixed couples are not as easy to answer as might at first appear. Official statistics only count married couples. Furthermore, aside from the general questions whether a difference in citizenship is the right indicator, it is important to decide if one wants to know something about flows (how many mixed marriages are concluded each year?) or about stock (how many couples in France are mixed?).

\section{Considering the flows}

To count French-foreign unions, it is usual to look at the number of marriages concluded each year (what statisticians call a flow). In 2005, 43,266 French-foreign unions were concluded (see table 1). They represented $15.3 \%$ of the 283,194 total number of marriages celebrated in France (i.e. 231,348 marriages between French citizens and 8,580 marriages between two foreigners of different nationalities). Mixed marriages are concluded somewhat more by French men (55.6\%) than by French women (44.4\%). Their number has greatly increased since 2000, compared to the preceding decade (in the 1990s the percentages fluctuated between 9 and 12\%). Despite considerable legal limitations on immigration, which concern French-foreign couples directly - verification of the marital project before immigration (a procedure which can last for more than a year), progressive access to a stable resident permitthe proportion of mixed marriages concluded every year remains high compared to the number of marriages between French citizens ${ }^{1}$.

Concerning the national origins of the foreign spouses of couples married in $2005,56.9 \%$ had arrived from the African continent, mostly from NorthAfrica (see tab. 2). 67\% of foreign men married to French women came from Africa, whereas only $33 \%$ of foreign women married to French men did. The second most important group of foreigners married with French citizens in 2005are Europeans: 24.8\%. For this group, foreign women married to French men are more numerous than foreign men married to French women $(57 \%$ vs. $43 \%$ ) (all these percentages are taken from the official report on migrants' presence in France, Régnard, 2007, p.175 and p. 290). We observe that mixed marriages occur with migrants coming from the most numerous immigrant groups in France.

1. Contrary to French citizens, who can live together without being married, foreigners in couples with French partners are obliged to marry if they wish to live and work in France; in that way, they unwittingly swell the number of mixed compared to non-mixed marriages. 
Table 1. Mixed marriages in France in 2005

\begin{tabular}{ccccc}
\hline & $\begin{array}{c}\text { Total number } \\
\text { of marriages }\end{array}$ & $\begin{array}{c}\text { French-French } \\
\text { marriages }\end{array}$ & $\begin{array}{c}\text { French-foreign } \\
\text { marriages }\end{array}$ & $\begin{array}{c}\text { Foreign-foreign } \\
\text { marriages }\end{array}$ \\
\hline$\%$ & 283,194 & 231,348 & 43,266 & 8,580 \\
& 100 & 81.7 & 15.3 & 3.0 \\
\hline
\end{tabular}

Source: INSEE, Etat civil, 2005

Table 2. National origin of foreign spouses

\begin{tabular}{crrr}
\hline $\begin{array}{c}\text { National origin of } \\
\text { the foreign spouses }\end{array}$ & Africa & Europe & Other countries \\
\hline & 24,623 & 10,739 & 7,904 \\
$\%$ & 56.9 & 24.8 & 18.3 \\
\hline
\end{tabular}

Source: INSEE, Etat civil, 2005

It is important to notice that these statistics can take only legally married couples into account. Since in France the percentage of people living together out of wedlock is high, marital statistics only give us a partial vision of reality. It must also be observed that these statistics do not inform us as to which marriages concern French citizens whose parents were migrants, and who may have come from the same country as the foreign spouse. They do not tell us either who among the French spouses were naturalised immigrants before marriage.

\section{Survey on new-entry migrants}

Considering the statistical reality from the migrant's point of view, was made possible by analysing data from a survey done in 2006 with 2.762 new-entry migrants from countries outside the European Economic Area (EEA) (PPM - DREES, 2006).

C. Régnard and I established a typology distinguishing the French spouses of the migrants according to the way they relate to immigration. Results show that $32.2 \%$ of the migrants in that survey are in a relationship with a French person born in France, whose parents were also born in France (no relation to immigration), 26.9\% live with a French citizen born in France whose parents were born abroad (indirect relation to immigration) and $28.6 \%$ have a foreignborn French partner whose parents were also born abroad (double relation to immigration) (see table 3). When we looked at the countries of origin of the French spouses or their parents, we observed that the foreign partner most usually came from the same country. Thus, through marriage, French individuals of immigrant descent maintain ties with their or their parents' country of origin; the integration process ${ }^{2}$ takes a long time and is accomplished over generations (Collet/Régnard, 2008, see also Collet/Régnard, 2011).

2. I.e. integrating the labour market or consumer society, and changes in cultural patterns might be quick, but marital choice shows that the integration process is longer lasting. 
Table 3. Typology of French spouses living with new-entry migrants in 2006

\begin{tabular}{lrr}
\hline French spouse, no relation to immigration (parents born in France) & 946 & $32.2 \%$ \\
French spouse, direct relation to immigration (parents born abroad) & 790 & $26.9 \%$ \\
$\begin{array}{l}\text { French spouse, double relation to immigration (him/herself born } \\
\quad \text { abroad and parents born abroad) }\end{array}$ & 841 & $28.6 \%$ \\
Marginal situations & 362 & $12.3 \%$ \\
Total number of mixed couples & 2,939 & $100 \%$ \\
\hline
\end{tabular}

Source: "PPM survey, first weave (2006). Analysis: B. Collet et C. Régnard.

These results cast a new light on French-foreign couples. Cultural differences might characterize the family reality of only one-third of mixed couples; the other two-thirds do not really overcome cultural affiliation. Among the latter there might be a slight proportion of arranged marriages. And among all categories, there might also be some 'fictitious' partnerships which were only intended to give access to the residence permit, but there are of course no statistics available. The main result of this categorisation is to show that official citizenship is not sufficiently precise to delve more deeply into the reality of mixed couples.

\section{Considering the stock}

Some surveys make it possible to look at the stocks of mixed couples, i.e. to answer the question: "How many migrants in France live as mixed couples?" Analysing data from the Study on family history - EHF (1999) conducted alongside the National census, Alexandra Filhon and Gabrielle Varro (2005) point out that mixed couples could be measured following three criteria: the partners' country of birth, different citizenships, and the fact that the respondents themselves had immigrated or not (i.e. born abroad). The proportion of mixed couples in France varies according to the categorisation chosen (see table 4).

A survey such as this one, that considers mixed reality according to population stocks (in opposition to population flow) yields high percentages of mixed couples whatever the measure applied: nearly one out of two persons born abroad today live with a French-born person.

It is then possible to look at the stock of mixed couples more precisely. When the country of origin of the immigrant partner is considered, some countries show a high percentage of mixed couples, which is the case of European countries in general (see table 5). For example, among 163,929 couples in France formed with at least one migrant from Spain, 68.5\% are mixed (Franco-Spanish couples). This percentage is lower for Portuguese migrants; only $41.8 \%$ live in mixed couples. The percentages are lower again for the North-African countries (less than 46\%) and very low (18.7\%) for Turkish migrants. A low percentage of mixed couples implies that many or most couples are formed by two migrants from the same country. For most countries, the migrant partner in the mixed couple is a woman. Migrants coming to 
Table 4. Proportion of mixed couples in France according to three categorisations

Country of birth:

born in a foreign country + French person born in France

Citizenship:

naturalised French citizens + French-born citizens

$60.0 \%$

Immigration:

immigrant + non-immigrant

$38.6 \%$

Source: Study on family history - (Etude de l'Histoire familiale, EHF 1999)

Table 5. Mixed couples and country of origin of the migrant partner

\begin{tabular}{lccc}
\hline $\begin{array}{c}\text { Country of origin of the } \\
\text { migrant spouse }\end{array}$ & $\begin{array}{c}\text { Total number } \\
\text { of couples }\end{array}$ & Mixed couples & $\begin{array}{c}\text { \% of migrant men in } \\
\text { the mixed couples }\end{array}$ \\
\hline Spain & 163,929 & 68.5 & 35.6 \\
Italy & 199,828 & 71.4 & 45.1 \\
Portugal & 287,045 & 41.8 & 24.6 \\
Other EU (15) & 172,600 & 74.6 & 30.0 \\
Other European countries & 125,716 & 66.9 & 29.5 \\
Algeria & 215,783 & 46.3 & 30.1 \\
Morocco & 186,924 & 36.1 & 22.6 \\
Tunisia & 86,545 & 45.5 & 32.4 \\
Other African countries & 132,078 & 47.8 & 23.9 \\
Turkey & 65,726 & 18.7 & 13.3 \\
Vietnam & 24,957 & 47.6 & 20.8 \\
Cambodia & 19,723 & 26.9 & 14.3 \\
Laos & 14,227 & 30.6 & 15.4 \\
Other Asian countries & 78,964 & 46.6 & 21.7 \\
America, Oceania & 48,765 & 72.0 & 25.9 \\
Total & $1,822,810$ & 52.9 & 28.7 \\
\hline
\end{tabular}

Source: Insee, Population Census, 1999.

France after the 1960s have lower percentages of mixed couples; the lowest is hold by Turkish migrants ${ }^{3}$.

These results also emerged from the representative survey on migrants carried out in 1992 (Tribalat, 1996). Mixed couples reflect migratory realities as much as they reflect personal family choices.

This statistical presentation reveals the very complex reality of mixed couples. But in the last analysis, mixed couples appear like a dominant phenomenon in French migratory reality. When we look at the flows, many foreigners marry French people every year. When we look at the stock, almost one out of two migrants is part of a mixed couple.

However, the final conclusion is inevitably that citizenship is not precise enough to decide if a couple is mixed or non-mixed. What is more, none of

3. Turkish immigration into France occupies a marginal position from several points of view: migrants from Turkey arrived later than North-African or Portuguese migrants and they were not used to the French language as were migrants from the former colonies. 
these analyses makes it possible to distinguish bi-cultural from similar-cultural couples, and there is no indication as to the number of bi-cultural couples among French citizens.

\section{Some theoretical considerations on 'mixedness'}

In the last section of this article, let's come back to some more sociological view of mixed couples. The question is if relation to migration or foreign origin of one spouse is precise enough to conclude on an intercultural reality of a couple. And more than that, I would say 'mixedness' is not only a question of intercultural features, it questions social order and reconsiders conjugal and family relations.

\section{Mixedness and the social order}

The basic question might be: "what distinguishes mixed couples from other couples?" In a sense, there are always cultural differences between partners, because partnership and family realities are always built upon the partners' personal socialisation and different family backgrounds (Berger, Kellner, 1988). Why are certain couples called "mixed", and others not?

A first answer is that mixed couples combine criteria, such as different citizenships, ethnic origins, languages or religions. But these more or less objective criteria quickly show their limits. Gender, age and social differences are usually not included in the definition, because gender difference is considered the norm of heterosexual couples, and social differences - which in the past was one of the main factors of differentiation, known as miscegenation (see also Merton below) - only strike the contemporary observer when the gap between the two spouses is perceived as "very great".

A second question is which cultural, ethnic or religious difference is to be considered pertinent to decide whether a couple is "mixed" or not? When a woman from the North of France meets a man from the South they remark cultural differences, but they are not considered a mixed couple by their entourage. Therefore, objective or cultural differences alone are not sufficient to define mixedness. Cultural, ethnic and racial differences only become significant when they are based on historical and socially constructed differentiations. Thus, it appears obvious that some differences are considered to be less "normal", less "ordinary" — and less acceptable - than others. Our reflection on mixedness must combine perceived differences with the existing social order and norms.

For a more theoretical construction, one must return to Robert K. Merton's work (1941). He characterised mixed couples by the fact that they were "outgroup" couples who flaunted the social order. They were not mixed because of being bi-cultural, but because their choice challenged the marital norms and group affiliations prevailing in society. He summarized his theoretical model as follows:

Merton's model must naturally be understood in the light of the segregated American society of the times. There are many examples in history or in cur- 
Merton's model of partner selection

\begin{tabular}{lll}
\hline \multicolumn{1}{c}{ Partner selection } & \multicolumn{1}{c}{ Conformity to norms } & \multicolumn{1}{c}{ Deviance } \\
\hline In-group & $\begin{array}{l}\text { Conform endogamy }= \\
\text { dominant partner choice }\end{array}$ & $\begin{array}{l}\text { Deviant in-group couples = age } \\
\text { or social difference }\end{array}$ \\
Out-group & $\begin{array}{l}\text { Conform exogamy = internatio- } \\
\text { nal marriages }\end{array}$ & Cacogamy = mixed couples \\
\hline
\end{tabular}

rent societies which show that conjugal mixedness is not only a question of different cultures but one of conformity or deviance with regard to social norms. I called this phenomenon 'mixogamy' in my $\mathrm{PhD}$ thesis (Collet 1996, see also 1998, p. 146). These norms may concern particular groups (social norms of minorities) or the whole society (law), norms also vary throughout history.

What we can criticize in Merton's approach is the fact that he insists very strongly on the deviant character of mixed couples, even the word he chose has a clearly negative connotation ("cacogamy"). We prefer the definition proposed by Bensimon \& Lautman in their article of 1974: by defining "mixed couples" as "those who provoke reactions in their social environment", these authors kept the idea of a deviant choice, but they qualified it as a "normal phenomenon in modern societies" (Bensimon \& Lautman, 1974, p. 30).

'Mixedness' as terminology also works better than 'transcultural hybridisation', because, to our way of thinking, couple and family adjustment or negotiation is not only a question of different cultures, but also a question of social and gender affiliations (Santelli/Collet, 2003). It is impossible to consider culture without taking into account the social stratification or personal identifications. According to occupation or educational level, the way culture is experienced is not the same. In anthropology, the dominant concept is 'culture', in sociology it is 'social stratification or affiliation'; post-modern, individualised societies are characterised by the intersectionality of these dimensions. Identity construction and societal positions are the outcome, in a joint perspective.

By calling these couples 'mixed' we wish to highlight the possibility of studying all the elements of social differentiation together: gender, cultural and social questions in their interdependency. Instead of carrying on with socially prescribed attributions - culture, religion, or skin colour - to define mixed couples, we propose to study social relations in process, and use the term mixedness in order to overcome the ascribed factors of membership (Collet/ Philippe, 2008). It is not enough to note differences between partners or the co-presence of diverse elements. When studying mixedness, we will look at how situations, in which those socially constructed differences are in contact - e.g. in private life- influence social relations and modify social reality.

\section{Mixedness and conjugal relations}

A second theoretical issue is the link of mixedness and partnership or family projects, and in a broader sense, love relationships. These questions bring me 
back to the basic issues of family sociology. What is a couple and how do the partners experience love?

First, it is necessary to recall that one should beware of idealised, romantic ideas of love — he/she is the only one for me and I will love him/her forever! and of the idea that a couple is always a long-lasting undertaking, that it is for life?

People fall in love for different reasons, they feel alone, they need somebody to assist or help them. Founding a family is only one option among many others, and it is not always present in the beginning of a partnership. Partners might also not agree on the options. For foreigners, the situation might be even more critical, because they are legally excluded, they are searching for jobs and social integration, they do not speak the language, they feel alone and different, but they are also discriminated against or even persecuted. In all migratory groups where the sex-ratio is unbalanced (more men or more women in migration), mixed marriages with members of the majority group are more frequent: Sub-Saharans African men in Spain for instance (Rodriguez-Garcia, 2006), or Russian women in France (Collet/Régnard, 2011). For the majority partner too, an intimate relationship with a foreigner or member of a minority group is in some ways special. He/She might confuse love and caring for somebody. It is also true that the love is more intense when your partner is discriminated against or when the two partners feel that their relationship is legally difficult, socially rejected (Romeo and Juliet complex). Generally speaking, the feeling of love is more intense at the beginning of a relationship. Love in a sense masks social and cultural differences. But love may also emerge out of a marriage of convenience (for the resident permit), and a love relationship may have other objectives as well (obtaining a resident permit, financial support, leaving one's parents, etc.). What A. Giddens called the 'relation per se' (1992) is rather rare in social reality.

Only by living with the partner for a certain amount of time, one can see if the couple is able to overcome the cultural and social differences existing in the relationship. The co-presence of partners in a couple with different cultural affiliations does not necessarily lead to "transcultural hybridation". The differences may remain clearly distinct.

Furthermore, differences in mixed couples are not on an equal footing either. Gender roles in couples are unequal, heterosexual couples reunite two persons with socially asymmetrical gender positions which might differ from one culture to another, from country of residence to minority culture. As to social positions, the partners might have the same social status (homogamy) or not (heterogamy). Beyond gender status and social class differences that exist in all couples, other hypotheses concern the unequal status of partners in mixed couples:

- We stressed above the difference of their legal status, when one partner is member of the host society and the other is not; that inequality has consequences on the partnership and family reality. 
- International classification of countries along criteria of economic development leads to the national cultures in contact being not equal, and migratory movements influence partnership reality. Perhaps, when the cultures in contact are less unequal, the inequality may have fewer consequences, e.g. couples of two members of the European Union.

- Religions in international and national contexts are not equal, e.g. the international status of Islam according to its perception in connection with geopolitical problems in the world. A religious confrontation might occur in couples where the partners are of different religions.

- Languages are not equal, they reflect the international classification of countries, English and Spanish are well off, but many countries have ethnic group languages or unwritten ones.

- Last, but not least, racial and ethnic memberships do not have equal standing. The partners of a black-white couple, even in Africa, are not equal according to each one's resources and depending on social perceptions.

The consequences of these inequalities are that the social and cultural hybridisation process does not take place on the basis of equal resources; the partners do not enter into the intercultural exchange with the same cards in hand. They choose different ways of adapting/adjusting to the situation. What must be stressed here is that only when both partners are able (and their children) to judge that the differences in their partnership are ethically equivalent (Achard, 1998, p. 260), can they establish an egalitarian social and cultural exchange.

Due to the results of several studies, I can point to the features that seem to be influential in combination: More than culture, social class is relevant. More than culture again, the definition of gender roles strongly affects family life. The only really influential factor connected to culture is religion, because religious practice penetrates all spheres of life. The broader social context also influences the exchanges that couples negotiate in their private life. When legal and social discrimination runs high, the private sphere cannot easily withstand it.

\section{Mixedness and family culture}

According to the above, one can study social and transcultural hybridisation processes - mixedness - but it is not possible to assume that all mixed couples are engaged in that kind of process. We can study family culture, using this term not as indicating ethnic and cultural origins, but as designating partnership and family practices in daily life.

The analysis of mixed couples' specific family cultures (both in their partnership and the children's education) showed us that their exchanges take on different social and cultural forms. Mixed couples may refer to the same main cultural definition, i.e. one of the partners adopts central aspects of his/her partner's cultural repository or from the dominant culture of the country of residence. 
- It might be the dominant French family model. This pattern is of course the most likely, because the dominant culture in the country of residence has a huge influence.

- It might also be the model of the cultural minority. Religious conversion to the minority partner's religion is a strong indicator of adaptation to the minority culture.

Gender seems to orient choices differently. Majority women seem to be more inclined to adopt the minority culture of men, whereas minority women seem to be more inclined to adopt the majority culture of the men. In both cases women adopt men's culture.

However, empirical studies also show that couples are able to invent new family lifestyles. They do not reproduce the major pre-established, cultural features, but are creative in several sections of life, elaborating new, reciprocal, social, gender and cultural exchanges. Communication is the principal characteristic of these couples, nothing is taken for granted: lifestyles, language use, rituals, education, holidays, every domain of private and public life are discussed and negotiated. In so doing they put a distance between themselves and their family of origin. These couples tend to recreate social networks with people who think and act as they do (Collet/Varro, 2000).

\section{Conclusion}

After this long demonstration of the phenomenon of mixedness in France, we wish to underline a few points in particular.

The legal and historical context is important, for it directly influences the social reality of mixed couples in general and their private reality in particular. Mixed couples are an important trend in French society, and have been regularly studied since social sciences became more widespread, but we also must point to the fact that the subject has not as yet attained sociological maturity. The concepts need to be more thoroughly theorized. Mixedness, seems to us the most promising theoretical approach for the future, which will become more prevalent in the years to come.

Several research scholars in France think and so do I that it is risky to go out from a reified definition of mixed couples. It is not enough to state that they are mixed because of more or less "objective", observable differences in belonging (citizenship, skin colour, surname, religion or culture). Their 'mixedness' is a construction which demands precise, empirical inquiry to discover how couples see themselves and what kind of identities they elaborate for their couple and their children. Taking off from this premise, we can study more fruitfully these couples' adjustment and negotiation processes, and their inventiveness when setting up mixed family cultures. 


\section{Bibliographic references}

ACHARD, Pierre (1998). «La norme par rapport à la notion de mariage mixte: tradition et modernité». In: Philippe, C.; Varro, G. \& Neyrand, G. (eds.). Liberté, égalité, mixité... conjugales, une sociologie du couple mixte. Paris: Anthropos. 251-276.

BarbarA, Augustin (1978). Les mariages mixtes. Thèse de doctorat. Paris: EHESS.

BelHadJ, Marnia (2003). "Choix du conjoint et stratégies matrimoniales de jeunes femmes françaises d'origine algérienne». Revue Européennes des Migrations Internationales, 19 (1), 195-222.

Bensimon, Doris \& LaUtman Françoise (1974). "Quelques aspects théoriques de recherche concernant les mariages mixtes», Ethnies, 4, 17-40.

BENSIMON, Doris \& LAUTMAN Françoise (1977). Un mariage, deux traditions. Chrétiens et Juifs. Paris: CNRS, Université de Bruxelles.

Berger, Peter \& Kellner, Hansfried (1988). «Le mariage et la construction de la réalité». Dialogue, 102, 6-23, [1960].

Borrel, Catherine \& Simon, Patrick (2005). «L'origine des Français». In: LefĖVRe, Cécile \& Filhon, Alexandra (eds.). Histoires de familles, histoires familiales: les résultats de l'enquête Famille de 1999. Paris: Les Cahiers de l'INED.

Collet, Beate (1993). "Couples mixtes en France, couples binationaux en Allemagne». Hommes \& Migrations, 1167, juillet 1993, 15-19.

- (1996). Mariage mixtes et citoyennetés en France et en Allemagne, Thèse de doctorat, EHESS, Paris.

- (1998). «Intégration et mixogamie en France et en Allemagne». In: PHILIPPE, Claudine. et alii. (eds.).

- (2000). «Binationale Paare und Familien in Frankreich und Deutschland. Die Auswirkungen des rechtlichen Status auf die Integrationsmodi inländisch verheirateter Ausländer». In: AlBER, Jean-Luc; Ossipow, Laurence; OUTEMZABET, Valerie \&, Waldis, Barbara (eds.). Mariages Tous Azimuts. Approche pluridisciplinaire des couples binationaux. Fribourg: Editions universitaires Fribourg, Suisse.

Collet, Beate \& Philippe, Claudine (eds.) (2008). Mixité(s). Variations autour d'une notion transversale. Paris, L'Harmattan.

Collet, Beate \& Regnard, Corinne (2008). «Rethinking Statistics on mixed couples in France: How to go beyond the global indicator of French Citizenship?». Unpublished paper on the European Conference on Population, Barcelona.

Collet, Beate \& REgnaRd, Corinne (2011). «La réalité socio-culturelle de la mixité franco-étrangère. Analyse de données statistiques d'une enquête auprès de primoarrivants». Revue européenne des migrations internationales, (forthcoming).

COllet, Beate \& SANTELli, Emmanuelle (2008). «La mixité au-delà des différences culturelles. Les choix conjugaux des descendants d'immigrés maghrébins». In: Collet Beate, Philippe Claudine (eds.)

Collet, Beate \& Varro, Gabrielle (2000). “'Das Fremde ganz nah'. 'Kulturelle Identität' in Konzept und Alltag binationaler Partnerschaften». Anthropolitain, $8,35-42$.

Les mariages mixtes (1974). Ethnies. Paris, La Haye: Mouton, 4.

Les mariages mixtes (1993). Hommes \& Migrations, $\mathrm{n}^{\circ}$ 1167, juillet 1993.

FILHON, Alexandra \& VARRO, Gabrielle (2005). «Les couples mixtes, une catégorie hétérogène». In: LEFÈvRE, Cécile \& FILHON, Alexandra (eds.). Histoires de familles, histoires familiales : les résultats de l'enquête Famille de 1999. Paris: Les Cahiers de l'INED.

GIDDENS, Anthony (1992). The Transformation of Intimacy. Sexuality, Love and Eroticism in Modern Societies. Cambridge: Polity Press. 
Guyaux, Anne; Delcroix, Catherine; Randane, Amina \& Rodriguez Evangelina (1992). Double mixte, la rencontre de deux cultures dans le mariage. Bruxelles: Contradictions, L'Harmattan, ADRI.

HAMAD, Anne-Marie (1981). Etude du mariage mixte: l'exemple franco-libanais. Thèse de doctorat. Paris: EHESS.

Hammar, Thomas (1994). Democracy and the Nation State: aliens, denizens and citizens in a world of international migration. Aldershort: Avebury.

Hammouche, Abdelhafid (1990). "Choix du conjoint, relations familiales et intégration sociale chez les jeunes Maghrébins». Revue Européenne des Migrations Internationales, 6 (1), 175-187.

- (1994). Mariages et immigration : la famille algérienne en France. Lyon: Presses Universitaires de Lyon.

KuOH-MOuKOury, Thérèse (1983). Les couples dominos. Paris: L'Harmattan.

Merton, Robert. K. (1941). «Intermarriage and the Social Structure». Psychiatry, 4 (August), 361-374.

NeYrand, Gérard \& M'sili, Marine (1995). Mariages mixtes et nationalité française. Les Français par mariage et leurs conjoints. Paris: L'Harmattan.

- (1996). Les couples mixtes et le divorce. Le poids de la différence. Paris: L'Harmattan.

PhilipPe, Claudine \& VARro, Gabrielle (1998). «Réflexions préliminaires». In: PHILIPPE, Claudine; VARro Gabrielle \& NeYrand Gérard (eds.) (1998). Liberté, Égalité, Mixité... conjugales. Une sociologie du couple mixte. Paris: Anthropos (Éd. Économica).

RÉGNARD, Corinne (2007). Immigration et présence étrangère en France en 2006 - Rapport de la Direction de la population et des migrations. Paris: La Documentation Française, 308 p.

Rodriguez Garcia, Dan (2006). "Mixed Marriages and Transnational Families in the Intercultural Context: A Case Study of African-Spanish Couples in Catalonia». Journal of Ethnic and Migrations Studies, 32 (3), 403-433.

SAD SAOUD, Hadjila (1985). "Le choix du conjoint: tradition et changement». Revue Européenne des Migrations Internationales, 1 (2), 118-130.

SANTElli, Emmanuelle \& COLlet, Beate (2003). "Comment repenser les mixités conjugales aujourd'hui? Modes de formation des couples et dynamiques conjugales d'une population française d'origine maghrébine». Revue Européenne des Migrations Internationales, 19 (1), 51-77.

SCHnApper, Dominique (1994). La Communauté Des Citoyens, Paris: Gallimard.

STREIFF-FENART, Jocelyne (1985). «Le mariage : un moment de vérité de l'immigration familiale maghrébine». Revue Européenne des Migrations Internationales, 1, (2), 131-143.

- (1989). Les couples franco-maghrébins en France. Paris: L'Harmattan.

- (1994). Problèmes de terminologie et ambiguïté de la notion. In: VARrO, G. et alii. (eds.).

- (2000). «Sauver la face et réparer l'offense : le traitement rituel des mariages mixtes dans les familles maghrébines immigrées». In: AlBER, J.-L. et alii. (eds.). Mariages tous azimuts. Approche pluridisciplinaire des couples binationaux. Fribourg: Éd. universitaires de Fribourg (Suisse).

Tribalat, Michèle (1991). Cent ans d'immigration. Paris: INED «Travaux et documents.

Tribalat, Michèle; Simon, Patrick \& Riandey, Benoît (1996). De l’immigration à l'assimilation. Paris: La Découverte, INED. 
VARRO, Gabrielle (1984). La femme transplantée. Une étude du mariage franco américain en France et le bilinguisme des enfants. Lille: Presses Universitaires de Lille.

- (2003). Sociologie de la mixité. De la mixité amoureuse aux mixités sociales et culturelles. Paris: Éd. Belin.

VArro, Gabrielle (ed.) (1995). Les couples mixtes et leurs enfants en France et en Allemagne. Paris: A. Colin.

Varro, Gabrielle; Streiff-Fenart, Jocelyne \& Philippe, Claudine (eds.) (1994). «Des mariages et des familles dits mixtes». In: LABAT, C. \& Vermes, G. (eds.), Cultures ouvertes, sociétés interculturelles. Du contact à l'interaction. Paris: L'Harmattan.

VinSONNEAU, Geneviève (1978). La relation du couple mixte entre Noirs-africains et Françaises. Thèse de doctorat en psychologie sociale. Paris: Université René Descartes. 